\title{
Do Platelet Rich Plasma and Folic Acid Reverse Experimental Induced Ovarian Failure: Emphasis on Folliculogenesis, and Ovarian Steroidogenesis
}

\author{
Wardah Abdullah Alasmari', Eman Mohamed Faruk ${ }^{1,2}$, Ola Elsayed Nafea ${ }^{3,4}$, \\ Hanan Fouad ${ }^{5,6}$, Dalia Ibrahim El-wafaey ${ }^{7}$ and Samia M. Manawy ${ }^{8}$ \\ ${ }^{1}$ Department of Anatomy, Faculty of Medicine, Umm Al-Qura University, Saudi Arabia \\ Original \\ ${ }^{2}$ Department of Histology and Cell Biology, Faculty of Medicine, Benha University, Egypt \\ Article \\ ${ }^{3}$ Department of Forensic Medicine and Clinical Toxicology, Faculty of Medicine, Zagazig \\ University, Egypt \\ ${ }^{4}$ Department of Clinical Pharmacy, College of Pharmacy, Taif University, Saudi Arabia \\ ${ }^{5}$ Medical Biochemistry and Molecular Biology, Faculty of Medicine, Cairo University, Egypt \\ ${ }^{6}$ Faculty of Medicine, Galala University, Egypt \\ ${ }^{7}$ Department of Anatomy and Embryology, Faculty of Medicine, Zagazig University, Egypt \\ ${ }^{8}$ Department of Anatomy, Faculty of Medicine, Benha University, Egypt
}

$\overline{ }$

\section{ABSTRACT}

Background: Valproic acid (VPA) is a commonly prescribed antiepileptic drug. VPA could mediate endocrinal reproductive dysfunction on a long-term use. This study was designed to evaluate the possible protective effects of platelet rich plasma (PRP) alone and PRP in combination with folic acid (FA) in a rat model of VPA induced ovarian failure.

Materials and Methods: Thirty-five adult rats were randomly divided into five equal groups and 14 female rats were used for PRP preparation as control, VPA, co-treated VPA with FA, co-treated VPA with PRP and co-treated VPA with FA and PRP groups. All treatments were administered for 90 days. The effects of PRP and/or FA against VPA were evaluated through assessment of ovarian oxidant/antioxidant biomarkers, hormonal assay of reproductive hormones, quantification of mRNA gene expression for ovarian steroidogenesis pathway-encoding genes. Histopathological examination of the ovarian tissues was implemented.

Results: Revealed that VPA exposure caused ovarian failure as documented by the decreased ovarian superoxide dismutase and catalase activities, increased ovarian malondialdehyde levels, diminished serum reproductive hormones concentrations and repressed the ovarian steroidogenesis pathway-encoding genes. In addition, VPA-induced marked ovarian histopathological alterations and impaired folliculogenesis. PRP and/or FA treatment improved ovarian function after VPA exposure. Adding FA to PRP produced more ovarian estrogen receptors immunoexpression than those produced by PRP alone. While other protective effects against VPA induced ovarian failure are equal between the two agents.

Conclusion: PRP exhibited a protective role against VPA-induced ovarian failure in adult rats. A combined PRP and FA therapy is superior to PRP alone to some extent.

\section{Graphical Abstract}

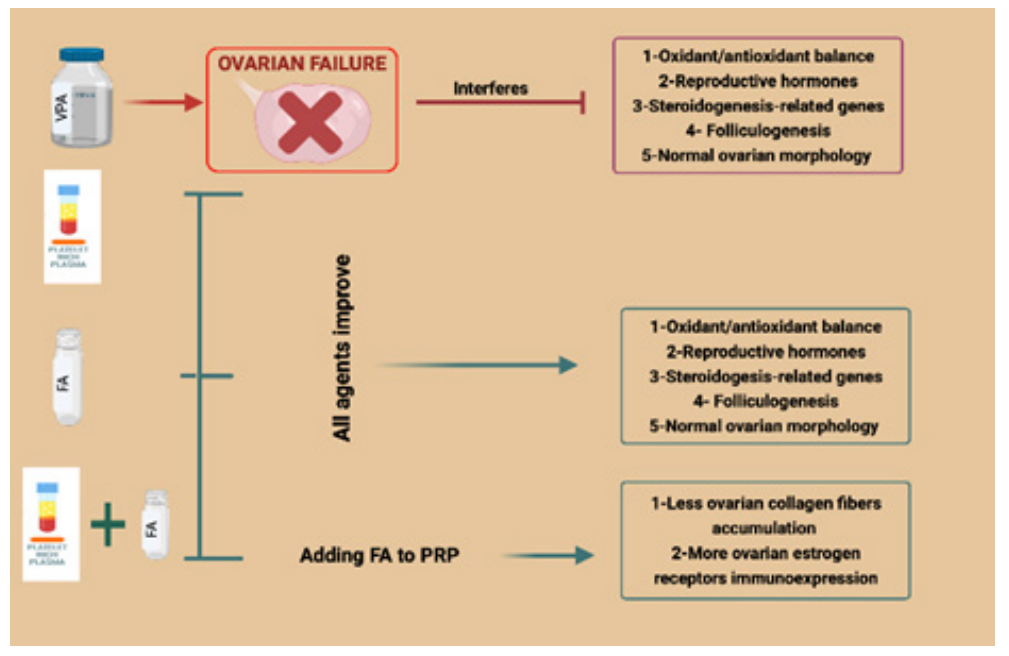


Received: 06 April 2021, Accepted: 06 May 2021

Key Words: Folic acid; ovarian failure; platelet rich plasma, steroidogenesis, valproic acid.

Corresponding Author: Eman Mohammed Faruk, MD, Faculty of Medicine Department of Histology and Cytology, Banha University, Banha, Egypt, Tel.: +20 1090693901 - +966 0596640779, E-mail: faruk_eman@yahoo.com

ISSN: $1110-0559$, Vol. 44, No.3

\section{INTRODUCTION}

The ovary is the primary regulator of reproductive and endocrine function. Principally, the ovary is responsible for folliculogenesis, gametes maturation for fertilization and biosynthesis of sex steroid hormones. Any interruption in the regulation of these processes can lead to reproductive and non-reproductive health consequences ${ }^{[1]}$.

Antiepileptic drugs (AEDs) negatively influence peripheral endocrine glands, hormones' synthesis, protein binding and serum sex hormones' activity with the resultant secondary endocrinal disorders. Valproic acid (VPA) was the first identified AED to cause metabolic and reproductive disturbances that may be more frequent with VPA than other AEDs; among these disturbances, hyperandrogenism, menstrual abnormalities, ovarian insufficiency, polycystic ovary syndrome (PCOs), hyperinsulinism and change in follicle-stimulating hormone (FSH), luteinizing hormone (LH) and thyroid hormones ${ }^{[2-4]}$.

Folates are water-soluble B9 vitamins. Folate is needed for the body to synthesize nucleic acids (DNA and RNA) and to metabolize amino acids critical for cellular division. Folic acid (FA) is the manufactured form of folate than can be utilized as nutritional supplements or fortified foodstuff. FA is essential for women reproduction, for example, oocyte maturation and quality, implantation, placentation, normal fetal growth and development. The World Health Organization listed FA as one of the essential medicines ${ }^{[5-8]}$. Moreover, inadequate FA intake has been linked to normal growth and development impairment, neural tube defects, DNA instability, cardiovascular complications and several types of cancers ${ }^{[9]}$.

Platelet rich plasma (PRP) is formed by a high concentration of platelets above that normally found in the whole blood, and has been utilized for the treatment of different pathological conditions, e.g., alopecia, diabetic wounds, osteoarthritis, skin and soft tissue damages ${ }^{[10-13]}$. Platelets have a remarkable role in wound healing and tissue repair secondary their content of $\alpha$-granules. The $\alpha$-granules contain above 800 various types of proteins that have a paracrine effect on surrounding cells, specifically on local mesenchymal stem cells, promoting a rapid tissue regeneration ${ }^{[14,15]}$. PRP can activate stem cells with subsequent improvement of tissue repair throughout migration, proliferation and differentiation of stem cells ${ }^{[16]}$.

In addition, PRP is rich in growth factors that are crucial for the healing process of damaged tissues and tissue regeneration as well as PRP can control vital cellular processes involving angiogenesis, mitogenesis, chemotaxis, differentiation, and metabolism ${ }^{[15,17,18]}$. PRP is linked to the process of oogenesis, increase of ovarian follicle count and release of estrogen hormone. Currently, various studies have been verified the valuable role of PRP in human and animal models of ovarian dysfunction ${ }^{[12,19-23]}$.

We hypothesized that PRP, alone and in combination with FA, can protect against VPA-induced ovarian failure in adult rats. We therefore studied the effect of PRP alone and PRP in combination with FA on ovarian oxidant/ antioxidant status, serum concentrations of reproductive hormones (estradiol, progesterone, FSH and LH), ovarian steroidogenic pathway-encoding genes; hydroxy-delta-5steroid dehydrogenase, 3 beta- and steroid delta-isomerase 2 (HSD3B2), steroidogenic acute regulatory protein (StAR) and 11ß-hydroxysteroid dehydrogenase-type 1 (11 $\beta$-HSD1) and the associated histopathological lesions. To authors' knowledge, this is the first study to explore the combined effect of PRP and FA in VPA evoked ovarian failure in adult female rats and to compare such effects to their relevant individual effects.

\section{MATERIALS AND METHODS}

\section{Materials}

We purchased VPA (Depakene ${ }^{\circledR}$ as oral solution $250 \mathrm{mg} / 5 \mathrm{ml}$, manufactured by Sanofi Aventis, Berlin, Germany) and FA (as a powder form dissolved in distilled water, from El-Gomhouria Company, Giza, Egypt).

\section{Preparation of PRP}

We used the double centrifugation tube method to get PRP from adult female Wistar rats ${ }^{[24-26]}$. In brief, rats were anesthetized intraperitoneally by injection of pentobarbital $(60 \mathrm{mg} / \mathrm{kg})^{[27]}$ and sacrificed by cervical dislocation then the whole blood was taken via cardiac puncture and collected into test tubes containing $3.8 \%$ sodium citrate anticoagulant at a blood/citrate ratio of 9/1. After that, the tubes were initially centrifugated at $400 \times \mathrm{g}$ for 10 minutes. Three different density components were formed; the uppermost layer composed of plasma and platelets; the lowermost layer composed of red blood cells whereas the middle layer composed of buffy coat of white blood cells. The plasma was taken with an automatic pipette without affection of the middle buffy coat and moved to another tube which was recentrifuged at $800 \times \mathrm{g}$ for 10 min. Plasma centrifugation resulted in two parts: the upper one composed of platelet-poor plasma (PPP) and the lower one composed of the platelet pellet. Most of the PPP was discarded while platelet pellet was smoothly agitated and then resuspended in phosphate-buffered saline (PBS) (1:1). Platelets were counted by an automatic analyzer to 
confirm that the platelet count was more than $1000,000 / \mu 1$. To activate PRP immediately prior use, $10 \% \mathrm{CaCl} 2(0.8 \mathrm{ml}$ PRP $+0.2 \mathrm{ml} \mathrm{10 \%} \mathrm{CaCl} 2$ ) was utilized.

\section{Animals}

The current study included 49 adult female Wistar rats weighing 180 to $200 \mathrm{~g}$. The animals were housed in plastic cages with $12 \mathrm{~h}$ light and dark cycles and allowed free access to food and water. For acclimation, the rats were handled manually for 2 weeks before commencing of the experiment to allow biological stabilization. All rats were chosen in their estrous phase of estrous cycle by the microscopic examination of vaginal smears to start the experiment in the same phase for all the study groups. All animals received humane care in compliance with the Animal Care Guidelines of the National Institutes of Health (NIH), and the Department of Anatomy, Faculty of Medicine, Benha University, approved the experimental design.

\section{Experimental protocol}

Fourteen female rats were used for PRP preparation as a donor group. Then the remaining 35 rats were randomly allocated animals into five groups of 7 rats each:

1. Group I (Control): Rats rreceived $0.5 \mathrm{ml} / \mathrm{kg}$ body weight of distilled water.

2. Group II (VPA): Rats received VPA in a dose of $200 \mathrm{mg} / \mathrm{kg}$ body weight, orally, once daily.

3. Group III (VPA+FA): Rats received VPA as in group II plus FA supplement in a dose of $400 \mu \mathrm{g} / \mathrm{kg}$ body weight, dissolved in $0.5 \mathrm{ml}$ of distilled water, orally, once daily.

4. Group IV [VPA+ (activated PRP) (aPRP)]: Rats received VPA as in group II plus aPRP of a dose of $0.2 \mathrm{ml} / \mathrm{kg}$ body weight, intraperitoneal (ip) injection, weekly.

5. Group V (VPA+FA+aPRP): Rats received VPA as in group II plus FA supplement as in group III plus aPRP as in group IV.

All treatments were administrated for 90 successive days. Doses of VPA, FA and PRP were selected based on earlier studies concerned with ovarian toxicities ${ }^{[20,28-31]}$.

\section{Samples collection}

On day 91 of the experiment, the rats were fasted overnight, then rats were anesthetized intraperitoneally with pentobarbital $(60 \mathrm{mg} / \mathrm{kg})^{[27]}$ for blood samples collection from the retro-orbital venous plexus for the separation of serum. Serum samples were obtained by centrifugation of blood at $2683 \times \mathrm{g}$ for $20 \mathrm{~min}$ and stored at $-20{ }^{\circ} \mathrm{C}$. The ovaries were excised immediately for biochemical analyses and histological/histochemical analyses.

\section{Ovarian Oxidant/antioxidant biomarkers assays}

Ovarian tissue samples were taken, ground with liquid nitrogen in a mortar. Then the ground tissues were treated with $4.5 \mathrm{ml}$ of PBS. The mixtures were homogenized on ice using an Ultra-Turrax homogenizer for $15 \mathrm{~min}$. Homogenates were used for estimation of the antioxidant [catalase (CAT) and superoxide dismutase (SOD)] enzymatic activities. Assay of (CAT) and (SOD) activities were done using commercially available kits according to manufacturer's recommendations (Thermofisher scientific, Cat No. EIASODC for SOD and Cat. No. EIACATC for CAT). Ovarian malondialdehyde (MDA), was estimated by the commercial kits supplied by Abcam (Cat. No. ab118970) according to manufacturer's recommendations.

\section{Hormonal assays}

Serum concentrations of estradiol, progesterone, FSH, and LH hormones were assessed by chemiluminescence based immunoassay using Siemens DPC Immulite ${ }^{1} 1000$ (Siemens Medical Solutions Diagnostics, Los Angeles, CA, United States).

\section{Assessment of steroidogenesis-related genes expression by real time polymerase chain reaction (PCR)}

Hydroxy-delta-5-steroid dehydrogenase, 3 beta- and steroid delta-isomerase 2 (HSD3B2), steroidogenic acute regulatory protein (StAR) and $11 \beta$-hydroxysteroid dehydrogenase-type 1 (11ß-HSD1) in the rats' ovarian tissues by real time PCR (qRT-PCR) using StepOnePlusTM real time PCR system (Applied Biosystems, USA). Total RNA was extracted from the tissue using RNeasy Mini Kit (Qiagen, USA, Cat No./ID: 74104). The extracted RNA was quantified by spectrophotometry (JENWAY, USA) at $260 / 280 \mathrm{~nm}$. Primers sequences used in the qPCR measurements for glyceraldehyde 3-phosphate dehydrogenase (GAPDH), HSD3B2, StAR and 11 $\beta$-HSD are displayed in Table 1. PCR primers were obtained from GenBank RNA sequences cited at the following website: https://www.ncbi.nlm.nih.gov/tools/primer-blast/. For the selection of the ideal primer pair, the considered factors included melting temperature (Tm: 60 to $65{ }^{\circ} \mathrm{C}$ ) and applicant length of about 90 to $200 \mathrm{bp}$.

\section{Real-time quantitative PCR using SYBR green}

Expression of HSD3B2, StAR and11 $\beta$-HSD genes were quantified with the StepOnePlus TM Real-Time PCR system software version 3.1 (Applied Biosystems, CA, USA). Optimization of the annealing temperature was conducted for the PCR protocol and for the primer sets. All cDNAs were prepared for all gene markers, GAPDH, and for non-template negative control. Five microliters of total RNA were used to generate cDNA using 20 pmol antisense primer and $0.8 \mu \mathrm{l}$ AMV reverse transcriptase at $37^{\circ} \mathrm{C}$ for $60 \mathrm{~min}$. The relative abundance of mRNA species was assessed by the SYBR ${ }^{\circledR}$ Green method (Applied Biosystems, CA, United States). Annealing temperature of $60{ }^{\circ} \mathrm{C}$ was optimized for all primer sets. Real time PCR was conducted in $25 \mu \mathrm{l}$ reaction volume consisting of Mater Mix of SYBR Green, $3 \mu \mathrm{l}$ of cDNA, $900 \mathrm{nmol} / \mathrm{l}$ of every primer. Amplification conditions were performed according to the 
manufacturer specifications: $2 \mathrm{~min}$ at $50{ }^{\circ} \mathrm{C}, 10 \mathrm{~min}$ at 95 ${ }^{\circ} \mathrm{C}$, 40 repeated cycles with $15 \mathrm{~s}$ denaturation and $10 \mathrm{~min}$ of annealing/extension at $60{ }^{\circ} \mathrm{C}$.

\section{Calculation of relative quantification (relative expression)}

Relative gene expressions of all assessed genes were calculated using the comparative Cycle threshold $(\mathrm{Ct})$ method $^{[32]}$. PCR data results show $\mathrm{Ct}$ values of the target genes and the housekeeping gene (GAPDH). A negative control sample was that no template cDNA used. Data were calculated using StepOnePlusTM real time PCR system (Applied Biosystems, CA, USA). All values were normalized to GAPDH housekeeping gene and expressed as fold changes relative to the background levels found in the control samples.

\section{Histological analyses}

The ovarian specimens were fixed in $10 \%$ buffered formalin solution for $24 \sim 48 \mathrm{~h}$, dehydrated in escalating grades of ethanol and embedded in paraffin. Serial sections of $3 \sim 5 \mu \mathrm{m}$ thickness was cut a by rotary microtome (LEICA RM 2125; UK) and subjected to the followings:

- Hematoxylin and eosin (H\&E) stain for histological assessment $^{[33]}$.

- Periodic Acid Schiff (PAS) stain is used to detect mucopolysaccharides e.g., glycogen ${ }^{[34,35]}$.

- Immunohistochemical stain for estrogen-betareceptors (ER- $\beta$ ). Ovarian sections were incubated for $120 \mathrm{~min}$ with anti-rabbit secondary antibodies (1:200 each; Vector Laboratories Inc., Burlingame, California, USA); an avidin-biotin-peroxidase method was used. After several rinses, the sections were mounted onto gelatin-coated slides and counterstained with Mayer's hematoxylin ${ }^{[36]}$.

\section{Histo-morphometric measurements}

Image-Pro Plus program (version 6.0; Media Cybernetics Inc., Bethesda, Maryland, USA) was used for histo-morphometric measurement. (Computer system in the morphometric unit in the Histology Department, Faculty of Medicine, Cairo University).

Five randomly selected high-power microscopic fields were inspected for counting the number of follicles, oestrogen positive cells at $\times 400$. Also, the area percentage of PAS polysaccharide substances were examined at $\times 20$. The results were expressed as mean area \% of collagen/ $\mu \mathrm{m}^{2}$.

Moreover, the area percentage of PAS polysaccharide substances and Mallory trichrome-stained collagen fibers were examined at $\times 20$. The results were presented as mean area $\%$ PAS polysaccharide substances and collagen $/ \mu \mathrm{m}^{2}$.

\section{Statistical analysis}

Continuous variables were presented as mean \pm standard deviation (SD). Shapiro-Wilk test and Bartlett's test were used to assess the normal distribution of the continuous variables and to check the equality of variance, respectively. According to the equality of variance, we used ordinary one-way analysis of variance (ANOVA) or Welch's ANOVA test detect statistical differences between groups. Tukey's test and Dunnett's T3 test post-hoc multiple comparisons tests were performed as appropriate. Differences were considered significant at a $P<0.05$. All statistical comparisons were two-tailed. Statistical analysis was conducted using Graphpad Prism, Version 8.0 Software (GraphPad Software; SanDiego, CA, USA).

\section{RESULTS}

\section{Death rates}

We recorded no deaths in all groups.

\section{aPRP and/or FA abated VPA-induced ovarian oxidant/antioxidant imbalance}

Chronic exposure to VPA for 90 days in adult rats evoked a significant decrease in ovarian SOD and CAT enzymatic activities but a significant increase in ovarian MDA levels compared with other groups of the study $(P<0.001)$. aPRP plus FA treatment did not elicit any significant changes in levels of ovarian oxidant/antioxidant biomarkers following VPA exposure compared with their respective individual effects $(P>0.05)$, as shown in Table 1.

\section{aPRP and/or FA adjusted VPA- altered ovarian steroid and gonadotropins hormones}

Serum progesterone, estradiol, FSH and LH concentrations significantly declined in VPA-intoxicated rats compared with other groups of the study $(P<0.001)$. aPRP treatment alone or in combination with FA produced a significant elevation in serum progesterone concentration compared with FA treatment alone $(P=0.03$ and $P<0.001$, respectively). aPRP plus FA treatment did not cause any significant changes in serum estradiol and gonadotropins (FSH and LH) hormones' concentrations in rats following VPA exposure compared with their individual effects $(P>0.05)$ (Table 2).

\section{aPRP and/or FA upregulated ovarian steroidogenesis-related genes' expressions following chronic VPA exposure}

aPRP plus FA treatment significantly upregulated ovarian steroidogenic genes (HSD3B2, StAR and $11 \beta$-HSD1) in comparison with VPA-exposed adult rats $(0.77 \pm 0.07,0.76 \pm 0.08$ and $0.83 \pm 0.077$-fold changes vs $0.58 \pm 0.059,0.59 \pm 0.061$ and $0.58 \pm 0.056$-fold changes, $P<0.001, P=0.03$ and $P<0.001$, respectively). Whereas aPRP plus FA treatment did not produced any significant alterations in ovarian steroidogenic genes' expressions following VPA exposure compared with their individual effects $(P>0.05)$ (Figure 1) 


\section{Histological results}

\section{Hematoxylin and eosin-stained ovarian sections}

H\&E-stained ovarian sections of control rats displayed the normal histological structure; covering germinal epithelium and cortex; follicles in different developmental phases (primordial, primary and secondary), atretic follicles, antral follicles and corpora lutea (Figure 2A). Ovarian sections of VPA-treated rats revealed absent of all types of follicles, except for subcortical secondary atretic follicles, multiple bulged cystic follicles with retained follicular fluid, non-ovulating antral like follicles that devoid of ova with zona pellucida, and atretic follicles surrounded by theca cells (Figure 2B). In addition, degenerated medulla was noticed with congested blood vessels, hyperplastic vacuolated luteinized theca cells and many spindle-shaped stromal cells in the cortex (Figure 2C). While ovarian sections of VPA+FA treated rats revealed a mild improvement in ovarian histology as some area showed a cellular cortex with multiple follicles; primordial, primary, secondary, antral follicles and corpora lutea along with a vascular medulla whereas other areas showed degenerated dilated cystic follicle and antral follicles (Figures 2D,E). However, adding aPRP treatment (VPA+aPRP and VPA+FA+aPRP) produced a moderate improvement in the ovarian histology as evidenced by the appearacne of all types of follicles (Figures 2F,G,H,I).

aPRP and/or FA increased the number ovarian follicles in different developmental phases (primordial, primary and secondary) and corpora lutea but decreased the number of atretic and cystic follicles following chronic VPA exposure

Chronic exposure to VPA for 90 days in adult rats led to a significant decrease in number of follicles (primordial, primary and secondary), antral follicles and corpora lutea $(P<0.001)$ but a significant increase in number of atretic and cystic follicles $(P<0.001)$ in comparison with other groups of the study. The effects of aPRP alone or in combination of FA on the number of ovarian follicles were similar in all development phases $(P>0.05)$. Likewise, the effects of FA and/or aPRP therapies on number of antral follicles were equal ( $\mathrm{P}>0.05)$. aPRP alone or in combination with FA significantly increased the number of follicles (primordial, primary and secondary) and corpora lutea compared to FA treatment alone $[(11.9 \pm 0.2,12.8 \pm 1.1$ vs $9.1 \pm 0.3, P<0.001$, each, respectively), (5.0 \pm 0.2 , $4.9 \pm 0.9$ vs $3.0 \pm 0.2, P<0.001$ and $P=0.009$, respectively)]. Co-administration of aPRP and FA significantly decreased the number of atretic follicles compared to FA alone (3.7 \pm 0.5 vs $5 \pm 0.2, P=0.003$ ). Also, the effect of each of these agents alone on number of atretic follicles was equal
(5.0 \pm 0.2 vs $4.7 \pm 0.8, P=0.98)$. aPRP alone or in combination of FA significantly decreased the number of cystic follicles compared to FA alone $(0.3 \pm 0.05,0.2 \pm 0.06$ vs $0.5 \pm 0.02$, $P<0.001$, each). Furthermore, aPRP plus FA treatment did not cause significant differences in number of antral follicles following VPA exposure compared to the use of each of these agents alone $(P>0.05)$ (Figure $2 \mathrm{~J})$.

\section{aPRP and/or FA restored ovarian carbohydrate depletion induced by chronic VPA exposure}

To evaluate the extent of carbohydrate distribution in rat ovarian tissues, we stained sections of ovarian tissues of all groups by PAS stain. In the control group, ovarian tissue showed a strong positive PAS reaction for carbohydrate distribution in the germinal epithelium basement along with the zona pellucida surrounding the oocyte (Figure 3A). While in VPA group, a faint positive PAS reaction of carbohydrate distribution in the ovarian cortex was detected (Figure 3B). Other treated groups showed a mild-to-strong PAS reactions (Figures 3C,D,E). Morphometric analysis of rat ovarian tissues revealed that mean area percent of ovarian PAS was significantly higher in VPA group than other groups of the study $(P<0.001)$. Mean area percent of ovarian PAS was comparable after aPRP and/or FA administration $(P>0.05)$ (Figure 3F).

\section{aPRP and/or FA reinstated the altered estrogen- $\beta$ receptors induced by chronic VPA exposure}

To evaluate the extent of ER- $\beta$ distribution in rat ovarian tissues, we stained sections of ovarian tissues of all groups by immunohistochemical stain for ER- $\beta$. Control group showed an intensive positive reaction for ER- $\beta$ in the nuclei of epithelial cells (granulose and theca cells) (Figures 4A,B). In VPA group, the ER- $\beta$ immunostaining was markedly weak (Figures 4C,D). Whereas in VPA+FA group, the ER- $\beta$ immunostaining was mild (Figure 4E). In both VPA+ aPRP and VPA+FA+ aPRP groups, a moderate to an intensive ER immunostaining was detected (Figures 4F,G). Morphometric analysis of optical density of ER- $\beta$-positive cells in ovarian tissues was significantly lower in VPA group than other groups of the study $(P<0.001)$. Optical density of ER ER- $\beta$-positive cells in ovarian tissues was significantly higher in combined aPRP and FA-treated rats than their respective individual effects (37.9 \pm 1.0 vs $34.9 \pm 0.5$ and $25.3 \pm 0.7, P<0.001$, each, respectively). Similarly, optical density of ovarian ER- $\beta$ positive cells was significantly higher in aPRP therapy than FA supplement in VPA-treated rats $(34.9 \pm 0.5$ vs $25.3 \pm 0.7$, $P<0.001$ ) (Figure 4H). 

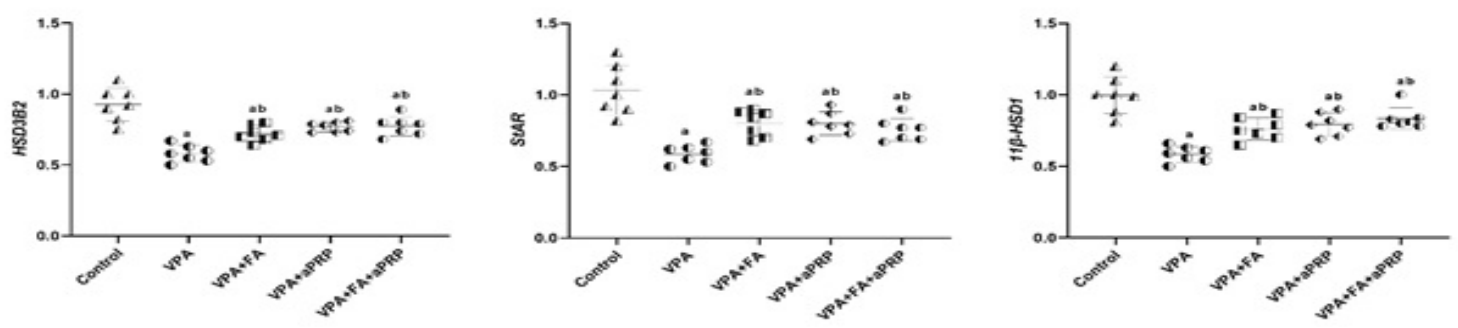

Fig. 1 Scatter dot plots showing the effects of aPRP and/or FA on ovarian steroidogenesis-related genes expression in VPA-intoxicated adult rats. a significant vs control group and b significant vs VPA group by ordinary ANOVA test followed by post hoc Tukey's multiple comparisons test, at P-value $<0.05$. Horizontal lines represent the mean and error bars represent the standard deviation. $\mathrm{n}=7$. Abbreviations; VPA, valproic acid; FA, folic acid; aPRP, activated platelet rich plasma; HSD3B2, hydroxy-delta-5-steroid dehydrogenase, 3 beta- and steroid delta-isomerase 2; StAR, steroidogenic acute regulatory protein; 11ß-HSD1, 11ß-hydroxysteroid dehydrogenase-type 1.
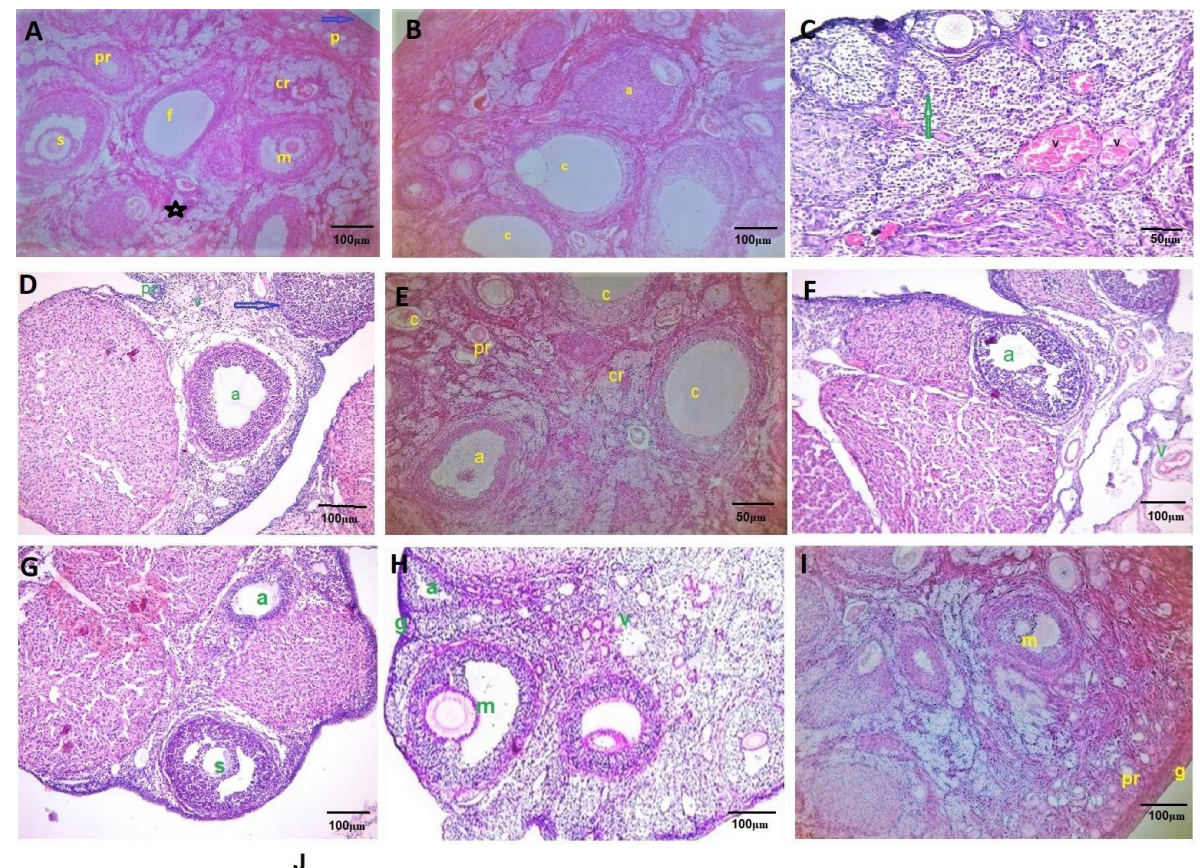

J

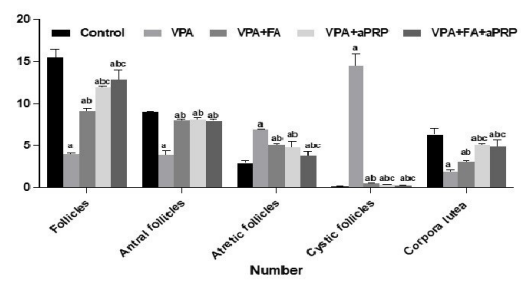

Fig. 2: Representative images of H\&E-stained ovarian sections of all groups: Fig. 2A Control group showing the covering germinal epithelium (arrow), the cortex contains (primordial follicles (p), primary follicle (pr), secondary follicle (s), mature Graafian follicle (m) and corpora lutea (cr). Notice the vascular medulla (star) and antral follicle (f). H\&E $\times 200$. Fig. 2B VPA group showing multiple cystic follicles with retained follicular fluid (c), non-ovulating antral like follicle that devoid of ova with zona pellucida (a). H\&E $\times 200$. Fig. 2C VPA group showing the degenerated medulla with congested blood vessels (v) and hyperplastic vacuolated luteinized theca cells with dark pyknotic nuclei (arrow). H\&E $\times 400$. Fig. 2D VPA+FA group showing antral follicle (a), primordial follicle (pr) and atretic (arrow). Notice the vascular medulla (v). H\&E $\times 200$. Fig. 2E VPA+FA group showing primordial follicle (pr), multiple small cystic follicles (c) and antral follicle (a). Notice that the corpus luteum (cr). H\&E $\times 400$. Fig. 2F VPA+aPRP group showing antral follicle (a). Notice the vascular medulla (v). H\&E $\times 200$. Fig. $2 \mathrm{G}$ VPA + aPRP group showing degenerated secondary follicle (s) and antral follicle (a). H\&E $\times 200$. Fig. $2 \mathrm{H}$ VPA $+F A+$ aPRP group showing cubical germinal epithelium $(\mathrm{g})$, mature Graafian follicle $(\mathrm{m})$ and antral follicle (a). Notice the vascular medulla $(\mathrm{v})$. H\&E $\times 200$. Fig. $2 \mathrm{I}$ $\mathrm{VPA}+\mathrm{FA}+\mathrm{aPRP}$ group showing multiple primordial follicles $(\mathrm{pr})$ and mature Graafian follicle $(\mathrm{m})$. Notice the germinal epithelium $(\mathrm{g})$. H\&E $\times 200$. Fig. $2 \mathrm{~J}$ Effects of aPRP and/or FA on the number ovarian follicles in different developmental phases in VPA-intoxicated adult rats. a significant vs control group, $b$ significant vs VPA group and c significant vs VPA+FA group by Welch's ANOVA test followed by Dunnett's T3 test post-hoc multiple comparisons tests, at P-value $<0.05$. Abbreviations; VPA, valproic acid; FA, folic acid; aPRP, activated platelet rich plasma. 

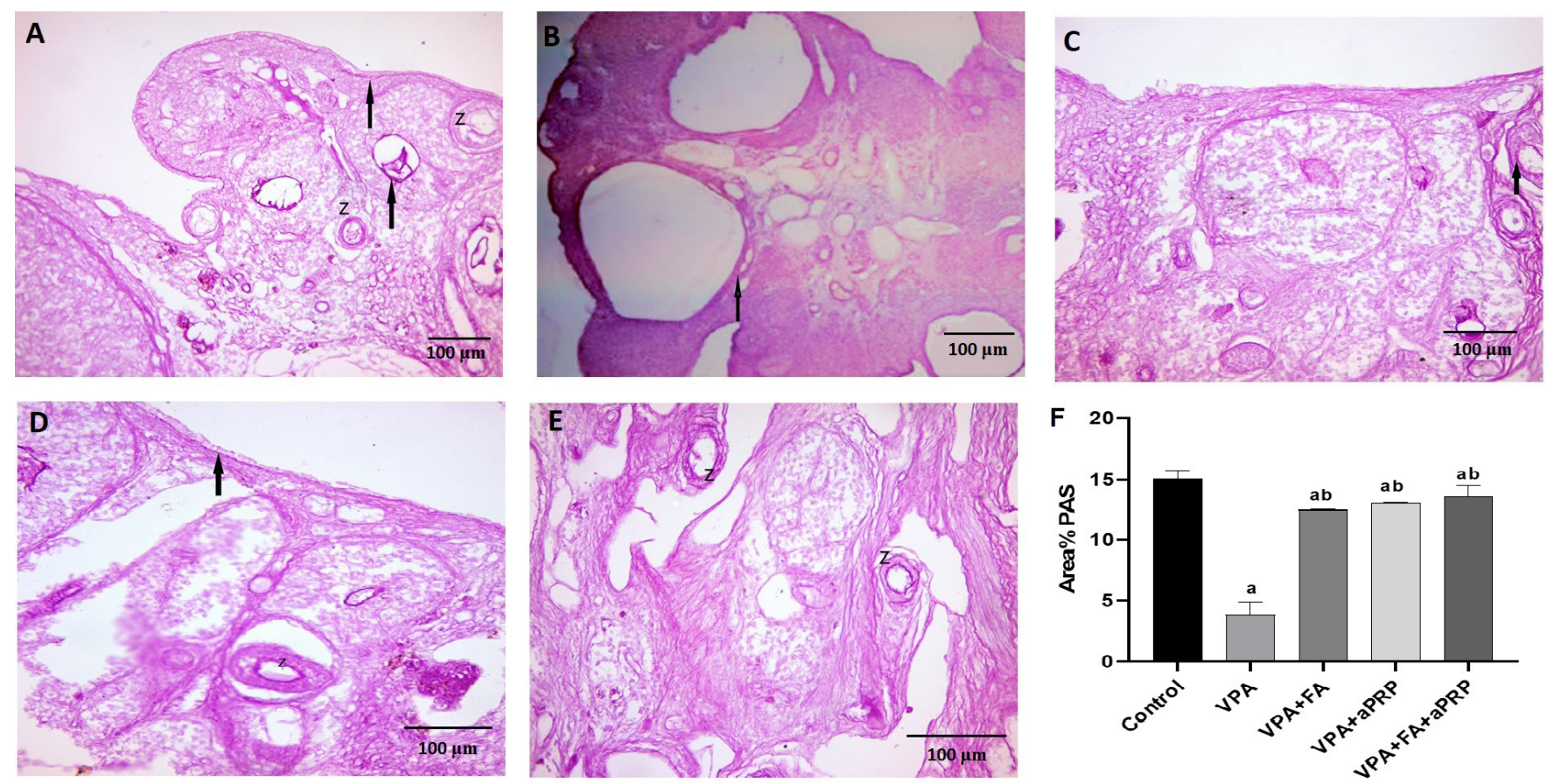

Fig. 3: Representative images of PAS reaction-stained ovarian sections of all groups. PAS reaction $\times 200$. Fig. 3A Control group showing a strong positive PAS reaction in the basement membrane of germinal epithelium (arrow) and the zona pellucida surrounding the oocyte (Z). Fig. 3B VPA group showing a faint PAS reaction (arrow) in the ovarian cortex and around ovarian cysts (arrow). Fig. 3C VPA+FA group showing a mild PAS reaction around ovarian (arrow). Fig. 3D VPA + aPRP group showing a moderate-to- strong PAS reaction (arrow) in the ovarian cortex and the zona pellucida surrounding the oocyte (Z). Fig. $3 \mathrm{E}$ VPA+FA+aPRP group showing a moderate-to-strong PAS reaction in the zona pellucida surrounding the oocyte (Z). Fig. 3F Effects of aPRP and/or FA on mean area percent of PAS in ovarian tissue in VPA-intoxicated adult rats. a significant vs control group and b significant vs VPA group by ordinary ANOVA test followed by post hoc Tukey's multiple comparisons test, at P-value $<0.05$. Data are mean \pm standard deviation, $\mathrm{n}=7$. Abbreviations; VPA, valproic acid; FA, folic acid; aPRP, activated platelet rich plasma; PAS, Periodic Acid Schiff. 

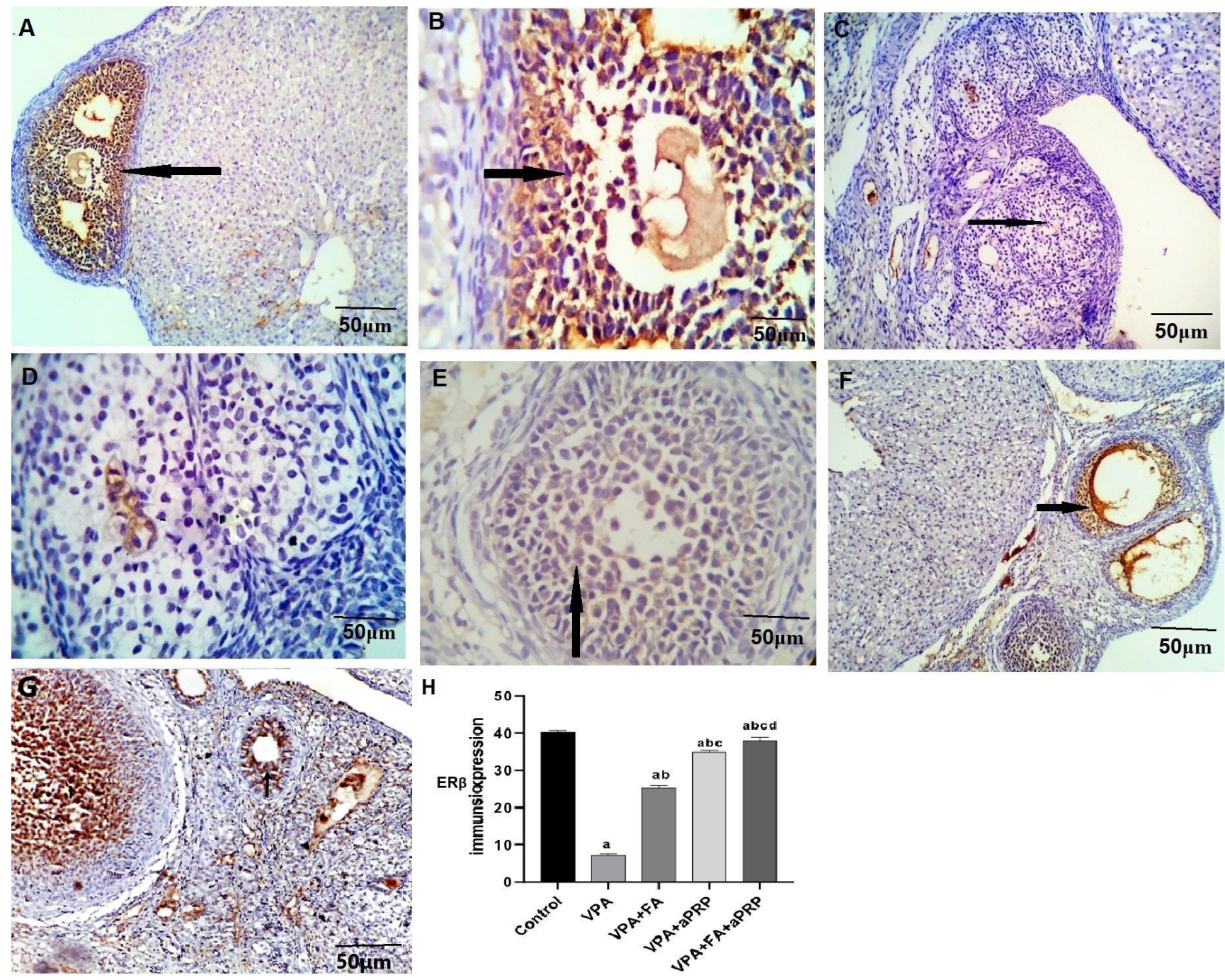

Fig. 4: Representative images of estrogen beta receptors $(E R-\beta)$ immunohistochemical stain for. ovarian sections of all groups. ER- $\beta$ immunostaining $\times 400$. Figs. 5A and B Control group showing a strong positive nuclear ER- $\beta$ immunoreactivity in the granulose cells of the growing follicles (arrow). Figs. 5C and D VPA group showing a markedly weak ER- $\beta$ immunoreactivity in the granulose cells of the growing follicles (arrow). Fig. 5E VPA+FA group showing a mild nuclear ER- $\beta$ immunoreactivity in the granulose cells of the growing follicles (arrow). Fig. 5F VPA+aPRP group showing a moderate nuclear ER- $\beta$ immunoreactivity in the granulose cells of the growing follicles (arrow). Fig. 5G VPA+FA+aPRP group showing a moderate-to-strong nuclear ER- $\beta$ immunoreactivity in the granulose cells of the growing follicles (arrow). Fig. $5 \mathrm{H}$ Effects of aPRP and/or FA on optical density of ER- $\beta$-positive cells in ovarian tissues VPA-intoxicated adult rats. a significant vs control group, b significant vs VPA group, c significant vs VPA+FA group and d significant vs VPA+FA + aPRP group by ordinary ANOVA test followed by post hoc Tukey's multiple comparisons test, at P-value $<0.05$. Abbreviations; VPA, valproic acid; FA, folic acid; aPRP, activated platelet rich plasma; ER, estrogen receptors.

Table 1: Primers sequences used in the quantitative polymerase chain reaction (PCR) measurements for the GAPDH, HSD3B2, StAR and $11 \beta-\mathrm{HSD} 1$

\begin{tabular}{ccc}
\hline Gene & \multicolumn{1}{c}{ Primers sequences } & GenBank ${ }^{\circledR}$ Accession Number \\
\hline \multirow{2}{*}{ GAPDH } & Forward: 5'- TTCACCACCATGGAGAAGGC -3' & NM_017008.4 \\
& Reverse: 5'-CCCAGGATGCCCTTTAGTGG -3' & \\
HSD3B2 & Forward: 5'- ACTGGATCCTCCAGCAAGGA -3' & NM_017265.4 \\
& Reverse: 5'-_ATGGAGAGAGCTCTGAGGTACA -3' & \\
StAR & Forward: 5'-CGTCGGAGCTCTCTACTTGG-3' & NM_031558.3 \\
& Reverse: 5'-CCCAAGGCCTTTTGCATAGC-3' & NM_017080.2 \\
\hline
\end{tabular}


Table 2: Effect of PRP and/FA on ovarian oxidant/antioxidant biomarkers, ovarian steroid and gonadotropins hormones in VPA-intoxicated adult female rats

\begin{tabular}{|c|c|c|c|c|c|}
\hline Parameters & Control & VPA & $\mathrm{VPA}+\mathrm{FA}$ & VPA $+\mathrm{aPRP}$ & $\mathrm{VPA}+\mathrm{FA}+\mathrm{aPRP}$ \\
\hline $\mathrm{SOD}(\mathrm{mmol} / \mathrm{min} / \mathrm{mg}$ tissue $)$ & $155.9 \pm 6.0$ & $85.4 \pm 5.6^{\mathrm{a}}$ & $137.2 \pm 6.8 \mathrm{ab}$ & $144.2 \pm 5.3^{\mathrm{ab}}$ & $141.1 \pm 6.0^{\mathrm{ab}}$ \\
\hline CAT ( $\mathrm{mmol} / \mathrm{min} / \mathrm{mg}$ tissue $)$ & $103.0 \pm 4.6$ & $64.3 \pm 5.5^{\mathrm{a}}$ & $73.1 \pm 4.3 \mathrm{ab}$ & $77.4 \pm 3.2^{\mathrm{ab}}$ & $76.8 \pm 3.8^{\mathrm{ab}}$ \\
\hline MDA (nmol/mg tissue) & $10.1 \pm 1.5$ & $23.8 \pm 1.7^{\mathrm{a}}$ & $15.3 \pm 2.6 \mathrm{ab}$ & $15.9 \pm 2.1^{\mathrm{ab}}$ & $13.5 \pm 2.2^{\mathrm{ab}}$ \\
\hline Progesterone $(\mathrm{ng} / \mathrm{mL})$ & $16.6 \pm 0.9$ & $5.2 \pm 0.6^{\mathrm{a}}$ & $12.0 \pm 0.9 \mathrm{ab}$ & $13.6 \pm 1.1^{\mathrm{abc}}$ & $14.7 \pm 1.0^{\mathrm{abc}}$ \\
\hline Estradiol (ng/L) & $43.5 \pm 2.0$ & $22.6 \pm 2.6^{\mathrm{a}}$ & $33.3 \pm 1.1 \mathrm{ab}$ & $34.6 \pm 0.7^{\mathrm{ab}}$ & $35.1 \pm 1.1^{\mathrm{ab}}$ \\
\hline FSH (IU/L) & $10.8 \pm 0.8$ & $7.1 \pm 0.7^{\mathrm{a}}$ & $0.90 \pm 0.8 \mathrm{ab}$ & $8.8 \pm 0.9^{\mathrm{ab}}$ & $9.2 \pm 0.9^{\mathrm{ab}}$ \\
\hline LH (IU/L) & $33.9 \pm 1.0$ & $22.5 \pm 1.5^{\mathrm{a}}$ & $29.9 \pm 2.2 \mathrm{ab}$ & $29.7 \pm 2.9^{\mathrm{ab}}$ & $30.7 \pm 1.7^{\mathrm{ab}}$ \\
\hline
\end{tabular}

All values are presented as mean $\pm \mathrm{SD}, \mathrm{n}=7$. a significant vs control group, $\mathrm{b}$ significant vs VPA group and $\mathrm{c}$ significant vs VPA+FA group within a row, by ordinary ANOVA or Welch's ANOVA test followed by Tukey's test and Dunnett's T3 test post-hoc multiple comparisons tests, respectively, at $P$-value $<$ 0.05. Abbreviations; VPA, valproic acid; FA, folic acid; aPRP, activated platelet rich plasma; SOD, superoxide dismutase; CAT, catalase; MDA, malondialdehyde; FSH, follicle-stimulating hormone; LH, luteinizing hormone.

\section{DISCUSSION}

It is well recognized that VPA has detrimental consequences on reproductive function in both sexes in human beings ${ }^{[3,30,37]}$. Ovarian failure is defined by steroid deficiency, ovulation defect, and atretic follicles increase. Altogether these factors can contribute to low follicular number, follicle dysfunction, and ultimately female infertility ${ }^{[38]}$. The present study verified the deleterious effects of VPA on ovarian function and structure in adult rats, as well as the protective effects of PRP, either individually or in combination with FA, against VPAinduced ovarian failure. Exposure to VPA for 90 days prompted ovarian functional distortions in adult rats as documented by disturbed ovarian oxidant/antioxidant balance, declined serum reproductive hormones concentrations, downregulated ovarian steroidogenic pathway-encoding genes along with the marked ovarian structural aberrations.

Oxidative stress (OS) is an initial cause of cell injury under normal physiological and pathological conditions. Antioxidant compounds safeguard against OS by mitigating the free radicals' burden and defend against molecular and cellular damages ${ }^{[39]}$. Imbalance between prooxidants and antioxidants molecules can end into reproductive disorders as unexplained infertility, endometriosis and PCOs in addition, pregnancy-related complications ${ }^{[40]}$. Our results showed that PRP and FA, either alone or in combination, equally reversed VPA evoked ovarian oxidant/antioxidant imbalance in adult rats. OS is one of VPA mechanisms implicated in many organ toxicities ${ }^{[41-44]}$. The wellknown antioxidant properties of FA could illuminate the recovered ovarian function and folliculogenesis during FA administration with VPA in our work ${ }^{[6]}$. In addition, the satisfactory effects of PRP against VPA induced ovarian injury could be clarified by its capability to assuage OS mediated injury and acceleration of ovarian tissue regenerative and repair processes by providing elevated levels of growth factors, cytokines and fibrinogen ${ }^{[45]}$. Intriguingly, PRP is enriched in growth factors which have imperative roles in ovarian tissues. These growth factors are key players in angiogenesis, cellular differentiation, proliferation and growth, extracellular matrix synthesis, chemotaxis, in addition, monitoring the release of other growth factors in very close proximity to their site of release ${ }^{[46]}$.

Steroidogenesis, the processes by which cholesterol is converted to biologically active steroid hormones, comprises transport proteins, enzymes, redox partners and cofactors. It is a series of reactions catalyzed by steroid cytochrome P450 (CYP) hydroxylases and hydroxysteroid dehydrogenases, for example type 2 HSD3B and type 1 $11 \beta$-HSD. Ovaries are one of the primary steroid-producing organs, producing estrogen and progesterone hormones, under the control of gonadotropins (FSH and LH hormones) during the estrous cycle ${ }^{[47]}$. Throughout steroidogenesis, the movement of cholesterol from the external to the internal mitochondrial membrane is considered as the rate-limiting step which is executed by StAR protein ${ }^{[48]}$. Substantial levels of $11 \beta$-HSD have been identified in the rat ovaries. The protein encoded by $11 \beta-H S D$ gene is $11 \beta-H S D$ enzyme that catalyzes the transformation of inert 11 keto-products (cortisone) to active cortisol, consequently, modulating the access of glucocorticoids to steroid receptors. Notably, glucocorticoids may affect ovarian function both indirectly and directly via binding to ovarian receptors ${ }^{[49,50]}$. HSD3B2 gene is primarily expressed in the adrenal glands and the gonads. The protein encoded by HSD3B2 gene is the enzyme that catalyzes the conversion of pregnenolone, $17 \alpha$-hydroxypregnenolone and dehydroepiandrosterone to progesterone, $17 \alpha$-hydroxyprogesterone and androstenedione. This enzyme is crucial for the biosynthesis of all classes of hormonal steroids ${ }^{[51]}$.

Our results demonstrated that VPA exposure intensely repressed ovarian steroidogenesis-related genes compared to control and other treated groups. PRP alone or in combination with FA supplement dramatically upregulated ovarian steroidogenic genes following VPA exposure. This upregulation of ovarian steroidogenesis-related genes could explain the associated increase in ovarian steroid and gonadotropins hormones after administration of PRP and/or FA following chronic exposure to VPA in adult rats. VPA mediates endocrinal reproductive dysfunction through peripheral and central effects ${ }^{[37]}$. In concordance with our observations, a work Gregoraszczuk et al. 
concluded that VPA decreased the release of estradiol and progesterone from follicular cells isolated from small- and medium-sized porcine ovarian follicles ${ }^{[52]}$. In support to our results, Ibrahim et al. found a significant decline in serum reproductive hormones concentrations (estradiol, progesterone, FSH and LH) in a rat model of VPA-induced ovarian failure compared with control group along with a marked elevation of their concentrations following FA supplementation ${ }^{[30]}$. Contradictory to our findings, a study of Røste et al. showed no significant alteration in serum progesterone and FSH in VPA-exposed rats in comparison with controls ${ }^{[37]}$. The alternation of the growing follicles count reflecting the alteration of ovarian steroid hormones concentrations $^{[31]}$.

Our observations revealed the marked ovarian morphological aberrations induced by VPA such as multiple bulged cystic follicles with retained follicular fluid. Earlier research reported comparable findings ${ }^{[28,30]}$. PRP and/or FA administration can ameliorate VPA elicited ovarian histopathological changes. FA is assumed to be essential in female reproductive function regulation. It plays a vital role in maintaining ovulation, oocyte quality and maturation ${ }^{[6,53]}$. The ovarian follicle serves as the functional unit of the ovary ${ }^{[54]}$. The ovarian endocrinal function is based on the ovarian follicle, which is responsible for formation of sex steroid hormones and maintenance of normal hormonal status with the hypothalamic-pituitary axis ${ }^{[55]}$. Likewise, Dehghani and colleagues found that PRP had a major protective effect against cyclophosphamide induced ovarian histopathological changes, such as increased the normal primary and antral follicle counts, improved follicular growth and development and accelerated ovarian tissue repair process ${ }^{[31]}$.

In our work, VPA negatively affects ovarian function and folliculogenesis. Rats exposed to VPA for 90 days showed depletion of primordial, primary and secondary follicles, antral follicles and corpora lutea along with predominance of atretic and cystic follicles compared to control rats and other treated rats. Notably, OS can contribute to impairment of ovarian functions as oocyte maturation, ovulation ${ }^{[56]}$. In agreement to our findings, Inada and coworkers stated that VPA causing ovarian dysfunction is mediated through suppression of follicular development and altered steroid hormone biosynthesis in cultured rat ovarian follicles ${ }^{[57]}$. Previous studies informed similar findings ${ }^{[28,30]}$. Conversely, Cansu and coworkers showed that the corpora lutea count significantly increased in a prepubertal rat model of VPA failure and attributed this increase to impaired follicles maturation ${ }^{[58]}$. This discrepancy could be explained by the variance in animals' age and dose of VPA used in their experiment.

We found that PRP alone or in combination with FA supplement exerts a similar effect regarding follicular development. However, PRP was superior to FA alone in most phases of follicular development. In corroboration, Ibrahim and colleagues elucidated the defensive role of FA supplement in VPA model of ovarian failure as supported by the increased count of ovarian follicles and corpora luteal but decreased atretic follicles count following VPA failure ${ }^{[30]}$. In the same vein, a study of Ozcan et al. showed the protective effect of PRP against cyclophosphamide induced ovarian injury in terms of a marked increase in number of primordial, primary, secondary and antral follicles but a noticeable decrease in atretic follicles number ${ }^{[20]}$.

Our results showed that VPA exposure for 90 days is associated with ovarian carbohydrate depletion as evidenced by PAS ovarian stained sections. Similarly, prior studies showed an intense positive PAS reaction in the zona pellucida surrounding the oocyte following exposure to antipsychotics as ovotoxin agents ${ }^{[59]}$. Ahmed et al. reported a strong positive PAS reaction following PRP therapy in a rat model of induced renal ischemia-reperfusion injury ${ }^{[60]}$.

In addition, VPA induced a marked ovarian collagen fibers accumulation. Comparable findings were presented by Abdelkader et al. who found an elevated hepatic hydroxyproline content and intense alpha smooth muscle actin protein overexpression, biomarkers for hepatic fibrosis, in hepatic tissues of VPA intoxicated rats ${ }^{[61]}$. Conversely, Kutlu et al. showed a decreased level of collagen fibers accumulation in corpus cavernosum in penile tissue of VPA-treated rats ${ }^{[62]}$.

In the same line of our results, Jang et al. found that PRP decreased endometrium fibrosis and hastened endometrium regeneration in a murine model of endometrial damage secondary to ethanol ${ }^{[63]}$.

We found that ER- $\beta$ immunoexpression significantly decreased in VPA-treated rats but the combined aPRP and FA treatment was superior to their individual effects. ER are nuclear receptors distributed intracellular of different tissues. ER are the target of estrogen hormone. The activated receptors control the activity of a variety of genes $^{[64]}$. Also, Anvari et al. demonstrated that PRP autolocated female rats revealed a significantly more intense estrogen receptors expression than PCOs female rats ${ }^{[65]}$.

\section{CONCLUSION}

Adult female rats exposed to VPA for 90 days developed ovarian failure as shown by the decrease serum concentrations of steroid hormones together with the intense repression of the ovarian steroidogenesis-related genes and the associated ovarian structural aberrations. Our results proved the protective role of PRP, alone and in combination with FA, against VPA-induced ovarian failure in adult rats. Whereas, adding FA to PRP produced less ovarian collagen fibers accumulation and more ovarian ER immunoexpression than those produced by PRP alone. Other protective effects against VPA induced ovarian failure were equal between the two agents.

PRP could be a promising therapeutic modality in women with ovarian failure/insufficiency in the clinical practices. 


\section{CONFLICT OF INTERESTS}

There are no conflicts of interest.

\section{REFERENCES}

1. Hannon PR, Flaws JA. The effects of phthalates on the ovary. Front Endocrinol (Lausanne) 2015;6 8

2. Markoula S, Siarava E, KeramidaA, et al. Reproductive health in patients with epilepsy. Epilepsy Behav 2020;113:107563

3. Verrotti A, Mencaroni E, Cofini M, et al. Valproic acid metabolism and its consequences on sexual functions. Curr Drug Metab 2016;17:573-581

4. Verrotti A, Greco R, Latini G, Chiarelli F. Endocrine and metabolic changes in epileptic patients receiving valproic acid. J Pediatr Endocrinol Metab 2005; 18:423-430

5. WHO. World Health Organization model list of essential medicines, 21 st list 2019. 2019. Geneva

6. Ebisch IMW, Thomas CMG, Peters WHM, Braat DDM, Steegers-Theunissen RPM. The importance of folate, zinc and antioxidants in the pathogenesis and prevention of subfertility. Hum Reprod Update 2007;13:163-174

7. Laanpere M, Altmäe S, Stavreus-Evers A, Nilsson TK, Yngve A, Salumets A. Folate-mediated one-carbon metabolism and its effect on female fertility and pregnancy viability. Nutr Rev 2010;68:99-113

8. West A, Caudill M, Bailey L. Folate. In: Marriott B, Birt D, Stallings V, Yates A (eds) Present Knowl. Nutr., 11th ed. 2020. Academic Press (Elsevier), London, UK, pp 273-288

9. Knott A, Mielke H, Koop U, et al. Folic acid: cellular uptake and penetration into human skin. J Invest Dermatol 2007;127:2463-2466

10. Lacci KM, Dardik A. Platelet-rich plasma: support for its use in wound healing. Yale J Biol Med 2010;83:1-9

11. Kavadar G, Demircioglu DT, Celik MY, Emre TY. Effectiveness of platelet-rich plasma in the treatment of moderate knee osteoarthritis: a randomized prospective study. J Phys Ther Sci 2015;27:3863-3867

12. Lubkowska A, Dolegowska B, Banfi G. Growth factor content in PRP and their applicability in medicine. J Biol Regul Homeost Agents 2012;26:3S-22S

13. Roohaninasab M, Goodarzi A, Ghassemi M, Sadeghzadeh-Bazargan A, Behrangi E, Najar Nobari N. Systematic review of platelet-rich plasma (PRP) in treating alopecia: focusing on efficacy, safety and therapeutic durability. Dermatol Ther 2021

14. Messora MR, Nagata MJH, Furlaneto FAC, et al. A standardized research protocol for platelet-rich plasma (PRP) preparation in rats. RSBO Rev Sul-Brasileira Odontol 2011;8:299-304
15. Drapeau C, Antarr D, Ma H, et al. Mobilization of bone marrow stem cells with StemEnhance $\AA$ improves muscle regeneration in cardiotoxin-induced muscle injury. Cell Cycle 2010;9:1819-1823

16. Pintat J, Silvestre A, Magalon G, et al. Intra-articular injection of mesenchymal stem cells and plateletrich plasma to treat patellofemoral osteoarthritis: preliminary results of a long-term pilot study. J Vasc Interv Radiol 2017;28:1708-1713

17. Branford OA, Klass BR, Grobbelaar AO, Rolfe KJ. The growth factors involved in flexor tendon repair and adhesion formation. J Hand Surg (European Vol 2014;39:60-70

18. Kang Y-H, Jeon SH, Park J-Y, et al. Platelet-Rich fibrin is a bioscaffold and reservoir of growth factors for tissue regeneration. Tissue Eng Part A 2011;17:349-359

19. Tobita M, Tajima S, Mizuno H. Adipose tissue-derived mesenchymal stem cells and platelet-rich plasma: stem cell transplantation methods that enhance stemness. Stem Cell Res Ther 2015;6:215

20. Ozcan P, Takmaz T, Tok OE, Islek S, Yigit EN, Ficicioglu C. The protective effect of platelet-rich plasma administrated on ovarian function in female rats with $\mathrm{Cy}$-induced ovarian damage. J Assist Reprod Genet 2020;37:865-873

21. Panda SR, Sachan S, Hota S. A systematic review evaluating the efficacy of intra-ovarian infusion of autologous platelet-rich plasma in patients with poor ovarian reserve or ovarian insufficiency. Cureus 2020;12:e12037

22. Cremonesi F, Bonfanti S, Idda A, Lange-Consiglio A. Platelet rich plasma for regenerative medicine treatment of bovine ovarian hypofunction. Front Vet Sci 2020;7

23. Cakiroglu Y, Saltik A, Yuceturk A, et al. Effects of intraovarian injection of autologous platelet rich plasma on ovarian reserve and IVF outcome parameters in women with primary ovarian insufficiency. Aging (Albany NY) 2020;12:10211-10222

24. Pazzini JM, Nardi AB De, Huppes RR, et al. Method to obtain platelet-rich plasma from rabbits (Oryctolagus cuniculus ). Pesqui Veterinária Bras 2016;36:39-44

25. El-Mahalaway AM, El-Azab NE-E. Impacts of resveratrol versus platelet-rich plasma for treatment of experimentally lithium-induced thyroid follicular cell toxicity in rats. A histological and immunohistochemical study. Ultrastruct Pathol 2019;43:80-93 
26. El Tahawy NF, Rifaai RA, Saber EA, Saied SR, Ibrahim RA. Effect of patelet rich plasma (PRP) injection on the endocrine pancreas of the experimentally induced diabetes in male albino rats: a histological and immunohistochemical study. J Diabetes Metab $2017 ; 08$

27. Leal Filho MB, Morandin RC, de Almeida AR, et al. Hemodynamic parameters and neurogenic pulmonary edema following spinal cord injury: an experimental model. Arq Neuropsiquiatr 2005;63:990-6

28. Røste LS, Taubøll E, Berner A, Isojärvi JI, Gjerstad L. Valproate, but not lamotrigine, induces ovarian morphological changes in Wistar rats. Exp Toxicol Pathol 2001;52:545-552

29. Aktaş A, Nergiz Y, Akkuş M. The effect of valproic acid on rat ovarium and the protective role of vitamin $\mathrm{E}$ and folic acid: An ultrastructural study. African J Biotechnol 2010

30. Ibrahim IH, Aboregela AM, Gouda RHE, Eid KA. Chronic valproate treatment influences folliculogenesis and reproductive hormones with possible ameliorating role for folic acid in adult albino rats. Acta Histochem 2019;121:776-783

31. DehghaniF,AboutalebiH,EsmaeilpourT,Panjehshahin MR, Bordbar H. Effect of platelet-rich plasma (PRP) on ovarian structures in cyclophosphamide-induced ovarian failure in female rats: a stereological study. Toxicol Mech Methods 2018;28:653-659

32. Livak KJ, Schmittgen TD. Analysis of relative gene expression data using real-time quantitative PCR and the 2- $\Delta \Delta \mathrm{CT}$ method. Methods 2001;25:402-408

33. Bancroft JD, Lyton C. The Hematoxylins and Eosin. In: Suvarna SK, Bancroft JD, Lyton C (eds) Theory Pract. Histol. Tech., 8th ed, Ed. 2019. pp 126-138

34. Layton C, Bancroft JD. Carbohydrates. In: Suvarna S, C L, Bancroft J (eds) Bancroft's Theory Pract. Histol. Tech., 8th ed. 2019. Elsevier, Philadelphia, pp 76-197

35. Bancroft J, Layton C. Connective tissue and other mesenchymal tissues with their stains. Bancroft's Theory Pract. Histol. Tech., 8th ed. 2019. Elsevier, Phialdelphia, pp 153-175

36. Sanderson T, Wild G, Cull AM, Marston J, Zardin G. Immunohistochemical and immunofluoresent techniques. Bancroft's Theory Pract. Histol. Tech., $8^{\text {th }}$ ed. 2019. Elsevier, Phialdelphia, pp 337-396

37. Sveberg Røste L, Taubøll E, Isojärvi JIT, et al. Effects of chronic valproate treatment on reproductive endocrine hormones in female and male Wistar rats. Reprod Toxicol 2002;16:767-773

38. Ebrahimi M, Akbari Asbagh F. Pathogenesis and causes of premature ovarian failure: an update. Int $\mathrm{J}$ Fertil Steril 2011;5:54-65
39. Iahtisham-Ul-Haq, Butt MS, Shamshad A, Suleria HAR. Heath benefits of anthocyanins in black carrot (Daucus carota). In: Goyal MR, Suleria HAR (eds) Hum. Heal. benefits plant Bioact. Compd. potentials Prospect. 2019. Apple Academic Press, New York, New York (NY)

40. Agarwal A, Aponte-Mellado A, Premkumar BJ, Shaman A, Gupta S. The effects of oxidative stress on female reproduction: a review. Reprod Biol Endocrinol $2012 ; 10: 49$

41. Gai Z, Krajnc E, Samodelov SL, Visentin M, KullakUblick GA. Obeticholic acid ameliorates valproic acid-induced hepatic steatosis and oxidative stress. Mol Pharmacol 2020;97:314-323

42. Ourique GM, Saccol EMH, Pês TS, et al. Protective effect of vitamin $\mathrm{E}$ on sperm motility and oxidative stress in valproic acid treated rats. Food Chem Toxicol 2016;95:159-167

43. Heidari R, Jafari F, Khodaei F, Shirazi Yeganeh B, Niknahad H. Mechanism of valproic acid-induced Fanconi syndrome involves mitochondrial dysfunction and oxidative stress in rat kidney. Nephrology 2018;23:351-361

44. Al-Amin MM, Rahman MM, Khan FR, Zaman F, Mahmud Reza H. Astaxanthin improves behavioral disorder and oxidative stress in prenatal valproic acid-induced mice model of autism. Behav Brain Res 2015;286:112-121

45. Martins RP, Hartmann DD, de Moraes JP, Soares FAA, Puntel GO. Platelet-rich plasma reduces the oxidative damage determined by a skeletal muscle contusion in rats. Platelets 2016;27:784-790

46. Fabi S, Sundaram H. The potential of topical and injectable growth factors and cytokines for skin rejuvenation. Facial Plast Surg 2014;30:157-171

47. Yazawa $\mathrm{T}$, Imamichi $\mathrm{Y}$, Sekiguchi $\mathrm{T}$, et al. Transcriptional regulation of ovarian steroidogenic genes: recent findings obtained from stem cell-derived steroidogenic cells. Biomed Res Int 2019;2019:1-13

48. Arukwe A. Steroidogenic acute regulatory (StAR) protein and cholesterol side-chain cleavage (P450scc)regulated steroidogenesis as an organ-specific molecular and cellular target for endocrine disrupting chemicals in fish. Cell Biol Toxicol 2008;24:527-40

49. Benediktsson $\mathrm{R}$, Yau JLW, Low $\mathrm{S}$, et al. 11ß-Hydroxysteroid dehydrogenase in the rat ovary: high expression in the oocyte. J Endocrinol 1992; 135:53-NP

50. Seckl JR, Walker BR. Minireview: 11ß-Hydroxysteroid Dehydrogenase Type 1- A Tissue-Specific Amplifier of Glucocorticoid Action 1. Endocrinology 2001;142:1371-1376 
51. Udhane S, Kempna P, Hofer G, Mullis PE, Flück CE. differential regulation of human $3 \beta$-hydroxysteroid dehydrogenase type 2 for steroid hormone biosynthesis by starvation and cyclic amp stimulation: studies in the human adrenal NCI-H295R cell model. PLoS One 2013;8:e68691

52. Gregoraszczuk E, Wójtowicz AK, TaubØll E, Ropstad E. Valproate-induced alterations in testosterone, estradiol and progesterone secretion from porcine follicular cells isolated from small- and medium-sized ovarian follicles. Seizure 2000;9:480-485

53. Altmäe S, Stavreus-Evers A, Ruiz JR, et al. Variations in folate pathway genes are associated with unexplained female infertility. Fertil Steril 2010;94:130-137

54. Woodruff TK. Making eggs: is it now or later? Nat Med 2008;14:1190-1191

55. Truman AM, Tilly JL, Woods DC. Ovarian regeneration: The potential for stem cell contribution in the postnatal ovary to sustained endocrine function. Mol Cell Endocrinol 2017;445:74-84

56. Sharma RK, Agarwal A. Role of reactive oxygen species in gynecologic diseases. Reprod Med Biol 2004;3:177-199

57. Inada $\mathrm{H}$, Chihara $\mathrm{K}$, Yamashita $\mathrm{A}$, et al. Evaluation of ovarian toxicity of sodium valproate (VPA) using cultured rat ovarian follicles. J Toxicol Sci 2012;37:587-94

58. Cansu A, Giray SG, Serdaroglu A, et al. Effects of chronic treatment with valproate and oxcarbazepine on ovarian folliculogenesis in rats. Epilepsia 2008;49:1192-1201

59. Khalaf HA, Elmorsy E, Mahmoud E-HM, Aggour AM, Amer SA. The role of oxidative stress in ovarian toxicity induced by haloperidol and clozapine-a histological and biochemical study in albino rats. Cell Tissue Res 2019;378:371-383

60. Ahmed SM, Mahmoud AA, Hassen EZ, Kader RRA. Light and electron microscope study on the effect of platelet-rich plasma in induced renal ischaemiareperfusion injury in the renal cortex of adult male albino rats. J Biochem Cell Biol 2018;1:110

61. Abdelkader NF, Elyamany M, Gad AM, Assaf N, Fawzy HM, Elesawy WH. Ellagic acid attenuates liver toxicity induced by valproic acid in rats. J Pharmacol Sci 2020;143:23-29

62. Kutlu Ö, Cansu A, Karagüzel E, et al. Effect of valproic acid treatment on penile structure in prepubertal rats. Epilepsy Res 2012;99:306-311

63. Jang H-Y, Myoung SM, Choe JM, et al. Effects of autologous platelet-rich plasma on regeneration of damaged endometrium in female rats. Yonsei Med J 2017;58:1195

64. Levin ER. Integration of the extranuclear and nuclear actions of estrogen. Mol Endocrinol 2005; 19:1951-1959

65. Anvari SS, Dehgan G, M. Razi. Preliminary findings of platelet-rich plasma-induced ameliorative effect on polycystic ovarian syndrome. Cell J 2019;21:243-252 
الملخص العربى

\section{هل البلازما الغنية بالصفائح الاموية وحمض الفوليك يعكسان فشل المبايض التجريبي المستحدث: التركيز على تكوّن الجريبات وتكوين الستيرويد المبيض}

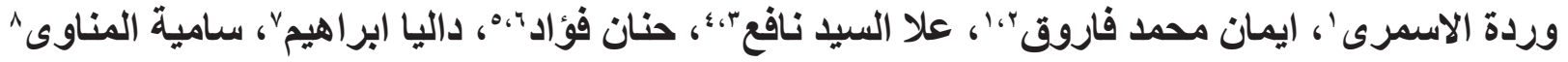

أقسم التشريح وعلم الأجنة _كلية الطب- جامعه ام القرى

"قسم الأنسجة وعلم بيولوجيا الخلية كلية طب بنها جامعة بنها

"قسم الطب الثرعي والسموم الإكلينيكيةــ كلية الطب- جامعه الزقازيق

قُقم الصيلة السريرية ـ كلية الصيدلة _جامعة الطائف

ققسم الكيميا كلية الطب جامعه القاهرة

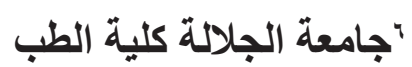

وقسم التشريح وعلم الأجنة كلية الطب جامعه الزقازيق

^قسم التشريح وعلم الاجنة كلية الطب جامعله بنها

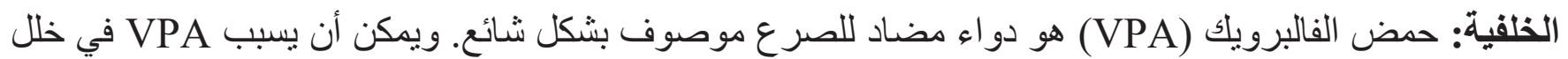

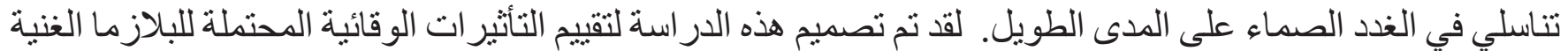
بالصفائح الدموية (PRP) وحدها و PRP بالاشتر الك مع حمض الفوليك (FA) في نموذج الفئر ان لفنل المبيض الناجم الفئ عن VPA. الطريقة: تم تقسيم هب فأرًا بالغًا بشكل عشو ائي إلى خمس مجموعات منساوية، واستخدمت ع ا أنتى من الفئران

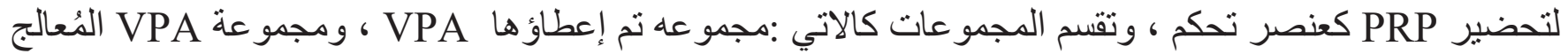

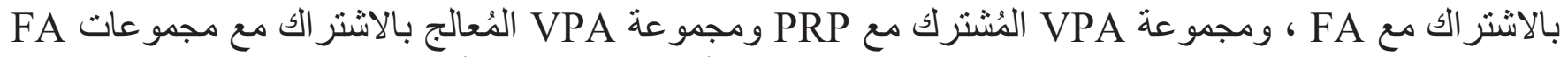

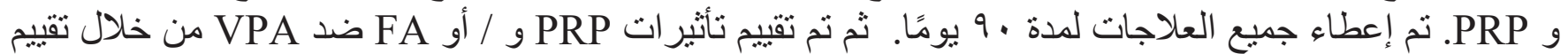

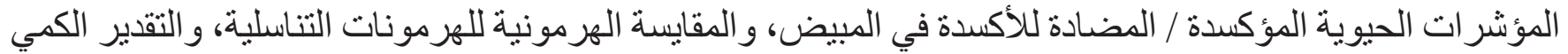

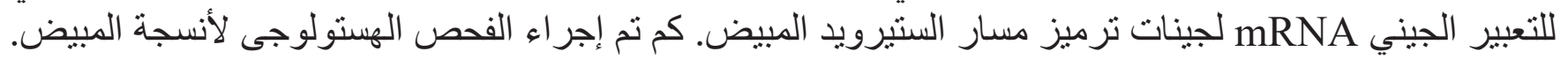

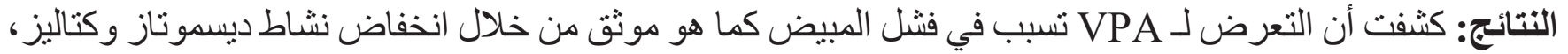

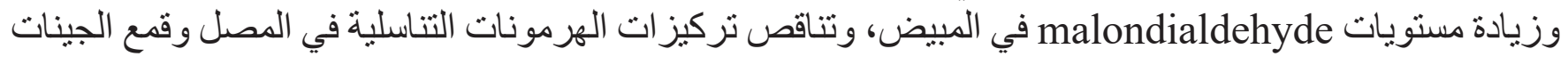

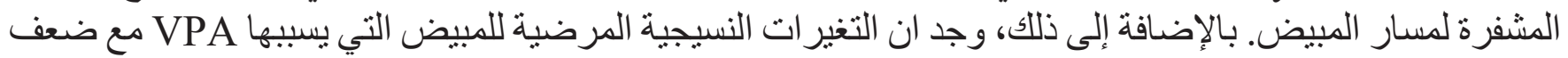

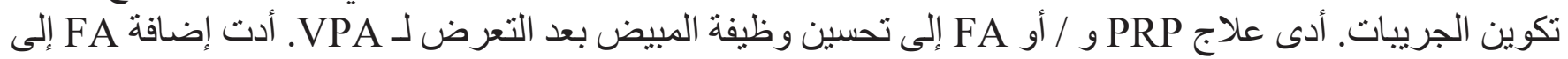
إلى تر اكم أقل لألياف الكو لاجين في المبيض والمزيد من التعبير المناعي لمستقبلات هرمون الاستروجين في

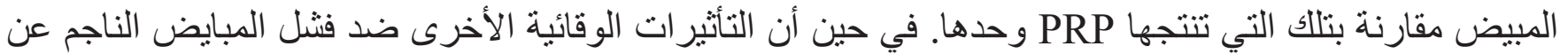
VPA

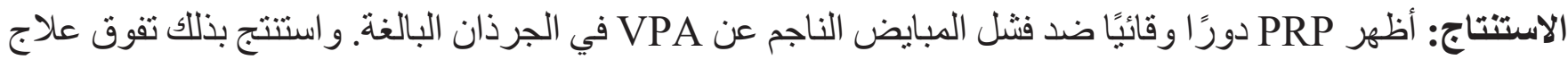

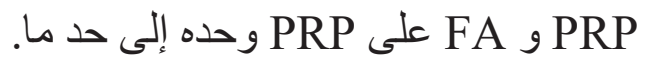

